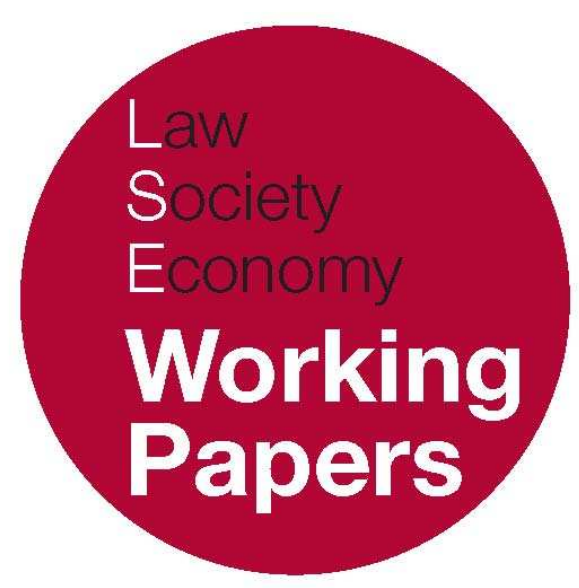

\title{
The Impact of Internationally Mandatory Laws on the Enforceability of Arbitration
} Agreements

\author{
Jan Kleinheisterkamp
}

LSE Law, Society and Economy Working Papers 22/2009

London School of Economics and Political Science

Law Department

This paper can be downloaded without charge from LSE Law, Society and Economy Working Papers at: www.lse.ac.uk/collections/law/wps/wps.htm and the Social Sciences Research Network electronic library at: http://ssrn.com/abstract=1496923.

(C) Jan Kleinheisterkamp. Users may download and/or print one copy to facilitate their private study or for non-commercial research. Users may not engage in further distribution of this material or use it for any profit-making activities or any other form of commercial gain. 


\title{
The Impact of Internationally Mandatory Laws on the Enforceability of Arbitration Agreements
}

\author{
Jan Kleinheisterkamp *
}

\begin{abstract}
This article examines the impact that internationally mandatory rules of the forum state may have on the effectiveness of arbitration agreements. This question arises when claims are based on such internationally mandatory rules, but the parties submitted their contract to a foreign law. The specific problems of conflicts of economic regulation are illustrated and discussed on the basis of Belgian and German court decisions relating to commercial distribution and agency agreements. European courts have adopted a restrictive practice of denying the efficacy of such tandems of choice-of-law and arbitration clauses if there is a strong probability that their internationally mandatory rules will not be applied in foreign procedures. This article shows that neither this approach nor the much more pro-arbitration biased solutions proposed by critics are convincing. It elaborates a third solution, which allows national courts to reconcile their legislator's intention to enforce a given public policy with the parties' original intention to arbitrate and to optimize the effectiveness of both public interests and arbitration.
\end{abstract}

\section{INTRODUCTION}

The role of internationally mandatory laws in arbitration and the associated questions of arbitrability are among the most controversial topics of international

\footnotetext{
* Law Department, London School of Economics and Political Science. All passages cited from German and Belgian court decisions are my translations. I would like to thank Mr. Gary Born as well as the participants of the ITA Academic Council Retreat of January 30, 2009, especially Professor Alan Rau and Professor Tai-Heng Cheng, for their insightful observations and remarks on an earlier version of this paper, entitled 'Reconciling Public Interests with Arbitration's Efficiency: Coping with Internationally Mandatory Rules'. All errors are, of course, exclusively mine. A revised version of this paper will appear in the World Arbitration and Mediation Review.
} 
arbitration. ${ }^{1}$ In particular, since the U.S. Supreme Court's path-breaking Mitsubishi decision in 1985 and its broad repercussions, especially in Europe, ${ }^{2}$ scholars and courts alike have struggled with these questions. They have been at pains to find coherent solutions for situations where parties entrust to arbitrators disputes in the outcome of which mandatory rules, other than those of the law chosen by the parties represented, have a particular interest. Internationally mandatory rules are by definition trouble-makers: they are designed by legislators to protect (or constructed by courts as implementing) local public interests that are supposedly so strong as to justify imposing given solutions "extraterritorially" irrespective of the proper (foreign) law governing the contract. ${ }^{3}$

This paper focuses on two European cases of 2006, one Belgian and one German, ${ }^{4}$ which exemplify the courts' struggle between respecting the parties' original intentions to arbitrate and their legislator's intention to protect public interests. ${ }^{5}$ In particular, these cases concern the impact of mandatory rules for the protection of sales intermediaries on arbitration agreements. This paper discusses the national courts' different approaches regarding the impact of the internationally mandatory rules of law and shows how their arguments are problematic both in terms of foundations and outcomes. In both cases, the

${ }^{1}$ See eg P. Mayer, 'Mandatory Rules of Law in International Arbitration' (1986) 2 Arb. Int'l 274; T.E. Carbonneau, 'The Exuberant Pathway to Quixotic Internationalism: Assessing the Folly of Mitsubishi' (1986) 19 Vand. J. Transnat'l L. 265; M. Blessing, 'Mandatory Rules versus Party Autonomy in International Arbitration' (1997) 14 J. Int'l Arb. 23; E.A. Posner, 'Arbitration and the Harmonization of International Commercial Law: A Defense of Mitsubishi' (1999) 39 Va. J. Int'l L. 647; P.J. McConnaughay, "The Risks and Virtues of Lawlessness: A "Second Look" at International Commercial Arbitration' (1999) 93 Nw.U.L.Rev. 453; A.T. Guzman, 'Arbitrator Liability: Reconciling Arbitration and Mandatory Rules' (2000) 49 Duke L.J. 1279; see also the numerous contributions to the colloquium at Columbia Law School on this topic at (2007) 18 Am. Rev. Int'l Arb.

2 Mitsubishi Motors Corp. v Soler Chrysler-Plymouth, Inc., 473 U.S. 614 (1985); for the European Community, see EcoSwiss China Time Ltd. v Benetton International NV C-126/97; [1999] ECR I-3055.

${ }^{3}$ Compare the formulation of the European Court of Justice in its Ingmar decision cited at $\mathrm{n} 34$ below with Art 9 of the Regulation (EC) 593/2008 of the European Parliament and the Council of 17 June 2008 on the law applicable to contractual obligations (Rome I): 'Overriding mandatory provisions are provisions the respect for which is regarded as crucial by a country for safeguarding its public interests, such as its political, social or economic organisation, to such an extent that they are applicable to any situation falling within their scope, irrespective of the law otherwise applicable to the contract under this Regulation.' See also \$187(2) Restatement 2nd of Conflict of Laws: '(2) The law of the state chosen by the parties to govern their contractual rights and duties will be applied, even if the particular issue is one which the parties could not have resolved by an explicit provision in their agreement directed to that issue, unless...(b) application of the law of the chosen state would be contrary to a fundamental policy of a state which has a materially greater interest than the chosen state in the determination of the particular issue and which, under the rule of $\$ 188$, would be the state of the applicable law in the absence of an effective choice of law by the parties.' For a basic overview over the notion of 'internationally mandatory rules', see T. Guedj, 'The Theory of the Loi de Police, A Functional Trend in Continental Private International Law - A Comparative Analysis With Modern American Theories' (1991) 39 Am. J. Comp. L. 661.

${ }^{4}$ In Belgium Cass., 16 November 2006, Van Hopplynus Instruments S.A. / Coherent Inc. [2007] Revue de Droit Commercial Belge 889; in Germany: OLG München, 17 May 2006 [2006] Wertpapier Mitteilungen 1556; [2007] Praxis des Internationalen Privat- und Verfahrensrechts 322.

${ }^{5}$ For a recent comparable case in the U.S., see Thomas v Carnival Corp., 2009 U.S. App. LEXIS 14406 (11th Cir. July 1, 2009) (regarding a claim by an injured seaman based on the remedies provided to injured seaman in the Seaman's Wage Act, where the contract provided for arbitration in the Philippines and Panamanian law as governing the contract). 
arbitration clauses were eventually held to be ineffective because of the danger that internationally mandatory laws designed to govern these situations would be circumvented by the use of arbitration. This paper aims at shedding more light on the nature of the inherent tension between arbitration and public interests. It shows that the traditional problem of arbitrability is often better framed as one of the impact of internationally mandatory rules, ie one of conflict of laws, and it proposes a practical solution that would allow courts to ensure both the protection of the involved public interests and the efficiency of the parties' choice for arbitration.

\section{THE EUROPEAN CASES}

The German and the Belgian case have almost identical fact patterns. What is striking is their resemblance to the highly controversial Ingmar case of the European Court of Justice of 2000, ${ }^{6}$ which is at the heart of the courts' dilemma and which will be presented later on. In both the German and the Belgian cases, a European national concluded a contract with a Californian producer for the exclusive sales of high-tech equipment in their respective countries. ${ }^{7}$ The contracts contained a choice-of-law clause in favour of Californian and U.S. law, plus different from the contract in Ingmar - provided for AAA arbitration in California. In both cases, the European claimants saw their contract terminated unilaterally by the Californians and initiated proceedings in their local commercial courts in order to obtain compensation or indemnification under German and Belgian legislation respectively. In both cases, the Californian defendants objected to the courts' jurisdiction on the basis of the arbitration clauses. The European claimants countered that these clauses would be ineffective or invalid due to the application of domestic internationally mandatory rules designed to guarantee their rights.

\section{The BELGIAN DeCISIONS}

The Belgian claim was based on an Act of 1961 which provides for mandatory indemnification for the concessionnaire if its 'exclusive sales concession of unlimited duration' is terminated unilaterally by the concédant, ie the provider. ${ }^{8}$ The quantification of the indemnification is basically dependent on the concessionnaire's

\footnotetext{
${ }^{6}$ Ingmar GB Ltd. v Eaton Leonard Technologies Inc. C-381/98; [2000] ECR 1-9305.

7 In the German case: semiconductor elements from Santa Clara for Germany, Austria, Hungary, Slovenia, the Czech Republic and Poland; in the Belgian case: laser-technology from Palo Alto for the Benelux and Congo.

8 Art 3 of Law of 27 July 1961: 'relative à la résiliation unilatérale des concessions de vente exclusive à durée indéterminée', Moniteur Belge of 5 October 1961.
} 
success in increasing the number of clients, its business investments, and its expenses suffered in consequence of the termination. The Act also provides that its provisions apply 'notwithstanding any contrary agreements concluded before the end of the contract granting the concession" Moreover, in order to secure its guarantees, the Act provides that the concessionnaire, 'in case of termination of a sales concession having its effects entirely or partially on Belgian territory, may always sue the provider in Belgium...[and] if the claim is brought before a Belgian court, this court will apply exclusively Belgian law'. ${ }^{10}$ It is uncontested that the provisions of the Act of 1961 constitute internationally mandatory rules in the above described sense (lois d'application immédiates/nécessaire). ${ }^{11}$

\section{The Question of the Law Governing Arbitrability}

The court of first instance, the Tribunal de commerce of Brussels, ${ }^{12}$ approached the problem as one of the law governing the arbitrability of the dispute under Article II(3) of the New York Convention (NYC). Previous case law and doctrinal writing had been - and still were until recently - deeply divided on this question..$^{13}$ The court referred to Article V(1)(a) NYC as allowing the parties to submit their arbitration agreement to a law of their choice. It also argued that aligning Article II(3) with Article V(2)(a) would oblige each country to apply its lex fori, which would mean potentially conflicting decisions on the validity of the arbitration agreement. Invoking the principle of favor arbitrandum, the court held - contrary to the internationally prevailing understanding ${ }^{14}$ - that the lex contractus, and not the lex fori, would govern the issue of arbitrability under Article II(3) NYC, ie Californian law. This reasoning then allowed the court to deny any impact of the Belgian Act of 1961. It referred to the primacy of international law over autonomous Belgian law, ${ }^{15}$ and based on its interpretation of Article II(3) NYC, deduced that it was obliged by the New York Convention to enforce the arbitration agreement because Californian law allowed the dispute to be arbitrated. 16

The Cour d'appel de Bruxelles upheld the referral to arbitration in $2002 .{ }^{17}$ In line with its previous case law, ${ }^{18}$ it confirmed the view that 'Articles II(3) and V(1) and

\footnotetext{
${ }^{9}$ Art 6 of Law of 17 July 1961.

10 Art 4 of Law of 17 July 1961.

11 See eg F. Rigaux and M. Fallon, Droit international privé (Brussells, Larcier, 2nd ed, 1993), para 1342; for the definition of internationally mandatory rules, see above text accompanying $\mathrm{n} 3$ above.

12 Com. Bruxelles, 5 October 1994, Van Hopplynus Instruments S.A. v Coherent Inc. [1995] Revue de l'Arbitrage 310-316, note B. Hanotiau.

13 See in detail P. Hollander, 'L'Arbitrabilité des Litiges Relatifs aux Contrats de Distribution Commerciale en Droit Belge' in L'Arbitrage et la Distribution Commerciale (Brussels: Bruylant, 2005), 29.

14 For the application of the lex fori under both Art V(2)(a) and II(3) NYC, see J.A. van den Berg, The New York Arbitration Convention of 1958: Toward a Uniform Judicial Interpretation (Alphen: Kluwer, 1981), 152-153 and the comparative references provided there.

15 For this primacy, see Cass., 27 May 1971, [1971-I] Pasicrisie 886.

16 Com. Bruxelles, n 12 above at [315].

17 CA Bruxelles, 7 February 2002 (unreported, extracts cited in the Cour de cassation decision cited at n 20 below).

18 Already CA Bruxelles, 4 October 1985 [1986] Journal des Tribunaux 93.
} 
(2) of the New York Convention leave no space for the application of the forum state's laws for determining the question of arbitrability of the dispute, and that this solution must be governed by the law applicable to the contract.' The court noted that 'if one were to stick to the [conflict] rules of internal law, the principle of party autonomy could never allow opting out of lois d'ordre public'. However, the court argued - rather confusingly - that the Act of 1961 would be 'merely' internationally mandatory (d'application immédiate), and not 'of public policy' (d'ordre public) in the sense of representing a public policy so essential as to stand in the way of the application of the result purportedly commanded by the New York Convention. ${ }^{19}$

This decision was quashed by the Cour de cassation. In its usual laconic way, it rejected the lower court's categorical exclusion of the lex fori under Article II(3) NYC:

This treaty provision does allow the judge to examine the question [of arbitrability] according to the law of the forum and to determine to what extent arbitration can be admitted for certain subject-matters. If the arbitration agreement is, like in the present case, subject to foreign law, the judge requested to decline its jurisdiction must exclude the arbitration if, by virtue of the lex fori, the dispute cannot be subtracted from the state courts' jurisdiction. ${ }^{20}$

\section{The Arbitrability of the Claims under Belgian Law}

By shattering the lower courts' lex contractus construction of Article II(3), the Cour de cassation also destroyed their shield against the Belgian internationally mandatory rules. The argument that superior international law would bar their application has now lost its foundation. The resulting question is therefore: does Belgian law prohibit disputes relating to the indemnification of exclusive distributors to be settled by arbitration? The decision of the Cour de cassation did not answer this question.

If one were to seek the answer in the literal wording of Article 4 of the 1961 Act ('the distributor...may always bring an action against the provider in Belgium'), the answer would have to be in the affirmative, since arbitration clauses aim at subtracting these claims from the Belgian courts. However, the Cour de cassation in its landmark decision Audi NSU had suggested already in 1979 an interpretation that was surprisingly liberal for the time:

\footnotetext{
${ }^{19}$ For this somewhat confusing qualification of the Act's provision as being d'application immédiate, but not d'ordre public, see also P. Hollander, 'Note - L'Arbitrabilité des Litiges en Matière de Résiliation de Concessions de Vente Soumises à la Loi Du 27 Juillet 1961: Fin de la Controverse ?' (2005) Revue de Droit Commercial 498, 502-503.

${ }^{20}$ Cass., 16 November 2006, Van Hopplynus Instruments S.A. v Coherent Inc. [2007] Revue Belge de Droit Commercial 889, note L. Mertens.
} 
These mandatory provisions aim at ensuring that the concessionnaire always has the right to invoke the protection of the Belgian law, except if he has relinquished [this protection] in an agreement concluded after the termination of the contract...A dispute arising out of the termination by the party that granted the exclusive sales concession that produced its effect totally or partially on the Belgian territory is, consequently, not capable of settlement by arbitration that was agreed before the termination of the contract and that has the aim and the effect of leading to the application of a foreign law (emphasis added). ${ }^{21}$

Although this decision only concerned an objection to enforcement of a foreign award rendered in Switzerland under Article V(2)(a) NYC, its significance for opening the door to arbitrability at the stage of enforcing the arbitration agreement becomes clearer when read in the light of another decision rendered just few months earlier. In the Bibby Line case,22 Belgium's highest court had upheld the effectiveness of a choice-of-forum clause in favour of Swedish courts that explicitly pointed to the internationally mandatory Belgian provisions as the applicable law. Noting that the respondent had not even alleged that Swedish law would prohibit the application of the chosen Belgian law, the Cour de cassation dismissed the appellate court's vague speculations on the uncertainty as to whether the Swedish court would apply Belgian law.

The spirit of these two decisions can also be found in the Gutbrot v. Usinorp decision of 1988.23 This case concerned the enforcement of an ICC arbitration clause, not under Article II(3) NYC, but under the unambiguous Article 6 of the European Convention of 1961, which submits the question of arbitrability explicitly to the lex fori. ${ }^{24}$ The lower courts had interpreted Audi NSU as meaning that 'an arbitration clause could only be valid if it specified that the arbitrators are obliged to apply the Belgian law [and] that if that is not the case, the clause could not stand because the distributor has no guarantee whatsoever regarding the applicable law and could thus loose the benefit to which he is entitled under the Act of 27 July 1961'.25 The lower courts had refused to enforce the arbitration clause because it seemed clear from the negotiations that the foreign party had inserted an arbitration clause in order to avoid the application of Belgian law. The defendant then sought cassation with the argument that the appellate court had failed to consider that the arbitrators, in absence of a choice-of-law clause, could well have found Belgian law to be applicable. The Cour de cassation rejected this

${ }^{21}$ Cass., 18 June 1979, Audi NSU v Adelin Petit S.A. [1979] Pasicrisie I 1260; [1979] Journal des Tribunaux 626 ; [1981] Revue Critique Juridique Belge 332, note R. Vander Elst.

22 Cass., 2 February 1979, Bibby Line v The Insurance Company of North America et al. [1979] Pasicrisie I 634.

${ }^{23}$ Cass., 22 December 1988, Gutbrod Werke GmbH v Usinorp de Saint-Hubert et Saint Hubert Gardening [1988] Journal des Tribunaux 458.

${ }^{24}$ Art 6(2) in fine of the European Convention on International Commercial Arbitration, done in Geneva on 21 April 1961, UNTS vol 484, 364, No 7041 (1963-1964): 'The courts may also refuse recognition of the arbitration agreement if under the law of their country the dispute is not capable of settlement by arbitration.'

${ }^{25}$ n 23 above. 
argument by simply finding that the lower court's judgment contained some reasoning on the law to be applied by the arbitrators and therefore did not violate the law. The lower court's reflection on the law to be applied by the arbitrators are rather questionable. Nevertheless, the fact that the Cour de cassation rejected the argument as unfounded but not a limine as irrelevant shows that it accepted this type of claim as not categorically excluded from settlement by arbitration. ${ }^{26}$

Accordingly, the impact of the Belgian mandatory rules of the 1961 Act on the arbitration agreement can be summarized as follows: As a rule, the literal reading of the provisions prevail so that disputes to which the 1961 Act is intended to apply are excluded from settlement by arbitration. However, an arbitration agreement can exceptionally be given effect if the party invoking the arbitration agreement can show that the arbitral tribunal is bound to apply the Act's provisions. ${ }^{27}$

\section{THE GERMAn DECISIONS}

In the German case before the Oberlandesgericht Munich, the parties had defined their relationship not as an exclusive distributorship, but as a commercial agency. ${ }^{28}$ Accordingly, the German claim was based on $\$ 89 \mathrm{~b}$ of the German Commercial Code (Handelsgesetzbuch - HGB), which obliges the principal to pay a equitable compensation to the commercial agent in case of termination of the contract (based on similar criteria as in the Belgian law).

\footnotetext{
${ }^{26}$ In this vein, see also the rather imprecise obiter dictum in Cass., 15 October 2004, Colvi S.A. v Interdica, (2005) Revue Belge de Droit Commercial 488 (only Flemish version): 'If an arbitration clause is subject, according to the intention of the parties, to foreign law, the judicial authority requested to decline its jurisdiction can exclude the possibility to resort to arbitration if this would violate its public policy' (emphasis added).

27 cf Hanotiau, n 12 above at [318], [323]-[324]; but see Hollander, n 19 above, 502-503 (trying to construe the arbitrability of claims based on the 1961 Act on the basis of the courts' distinction between 'merely' internationally mandatory rules and loi d'ordre public, arguing that it is accepted that the 1961 does not belong to the Belgian ordre public). This streak of case law has also shaped the provisions on the enforcement of jurisdictional clauses (but not arbitration clauses) of the new Belgian Code on Private International Law, published in the Moniteur Belge of 27 July 2004: 'Article 7 - If the parties, in a subjectmatter in which they can dispose freely of their rights according to Belgian law, have validly agreed to entrust the decision on disputes which have arisen or may arise out a legal relationship to the courts of a foreign state..., a Belgian judge seized in that matter must stay proceedings, unless it is foreseeable that the foreign decision could not be recognized or enforced in Belgium or that Belgian courts have jurisdiction according to Article 11. The judge will decline its jurisdiction if the foreign decision is susceptible of being recognized according to the present law' (emphasis added) and 'Article 11 - Notwithstanding the other provision of this law, Belgian courts exceptionally have jurisdiction if the case has close links with Belgium and if proceedings abroad turn out to be impossible or if it can not reasonably be required to bring a claim abroad (emphasis added).

${ }^{28}$ Furthermore, the parties had included not only an arbitration clause, but also a parallel choice-of-forum clause aimed at conferring exclusive jurisdiction to the courts of Santa Clara in California, which was not relevant for the outcome.
} 


\section{The Role of European Law}

\89b HGB is the German provision transposing Article 17 of the European Directive on Self-Employed Commercial Agents of 1986, ${ }^{29}$ which obliged all Member States of the EC to provide for mandatory indemnification (the German model) or compensation (the French model). ${ }^{30}$ It is worth noting that, to date, the European Community has only enacted two directives for the harmonization of European commercial contract law, 31 which highlights which importance the European legislator attributed to them. The European Court of Justice had to address the mandatory nature of Article 17 of the Directive in its controversial Ingmar decision of 2000.32 Like our German case, Ingmar also involved a European (English) commercial agent whose contract had been terminated by its Californian principal, and the contract contained a choice-of-law clause in favour of Californian law (yet without any jurisdiction or arbitration clause). In that case, the ECJ was asked by the English Court of Appeal to give a preliminary ruling on the question of whether the national provision transposing Article 17 of the Directive would prevail over the law of a non-EC country chosen by the parties. ${ }^{33}$ The ECJ answered in the affirmative by resorting to the distinction between (merely domestically) mandatory rules protecting group interests and (internationally) mandatory rules protecting institutional interests:

The purpose of the regime established by Articles 17 and 18 of the Directive is...to protect, for all commercial agents, freedom of establishment and the operation of undistorted competition in the internal market...It must therefore be held that it is essential for the Community legal order that a principal established in a non-member country, whose commercial agent carries out activity within the Community, cannot evade those provisions by the simple expedient of a choice-of-law clause. The purpose served by the provisions in question requires that they be applied where the situation is closely connected with the Community, in particular where the commercial agent carries on his activity in the territory of a Member State, irrespective of the law by which the parties intended the contract to be governed..$^{34}$

The ECJ thereby left no doubt that choice-of-law clauses that would undermine the solution intended by the European legislator are without effect because of the internationally mandatory character of the national law transposing the Directive.

\footnotetext{
${ }^{29}$ Council Directive 86/653/EEC of 18 December 1986 on the coordination of the laws of the Member States relating to self-employed commercial agents [1986] O.J. L382/17.

${ }^{30}$ For the rationale behind the alternative remedies, see F. Reynolds, Bowstead and Reynolds on Agency (UK: Sweet and Maxwell Ltd, 18th ed, 2006), 707.

31 The other one being Directive 2000/35/EC of the European Parliament and the Council of 29 June 2000 on combating late payments in commercial transactions [2000] O.J. L200/35.

32 ECJ, 9 November 2000, C-381/98, Ingmar GB Ltd. v Eaton Leonard Technologies Inc. [2000] ECR I-9305.

33 Ingmar GB Limited v Eaton Leonard Technologies Inc. [1999] E.C.C. 49 (CA).

${ }^{34}$ ECJ C-381/98, n 32 above at [24]-[25].
} 


\section{The Impact of $\int 89 b$ HGB on Jurisdictional Issues}

Ingmar only concerned the effectiveness of choice-of-law clauses. But what impact does the internationally mandatory character of the national law transposing the Directive have on choice-of-forum and arbitration clauses? Ironically, it was also in 1961, the year in which Belgium explicitly enacted internationally mandatory legislation to protect Belgian distributors, that the highest German court, the Bundesgerichtshof $(\mathrm{BGH})$, had frustrated the claim of a German commercial agent by confirming the effectiveness of a clause providing for the jurisdiction of Dutch courts and the application of Dutch law. This decision was based on the former understanding that the - largely identical - predecessor of $\$ 89 \mathrm{~b}$ HGB was not internationally mandatory. ${ }^{35}$ The situation in 1961 was thus different from that in 2004, the year in which the present case started: the provision had, due to its new European pedigree and its supposedly strategic role for the internal market, grown into an internationally mandatory rule.

In our German case, the court of first instance, the Landgericht Munich, had enforced the arbitration clause by referring the parties to arbitration. ${ }^{36}$ It merely held that its jurisdiction could not depend on some uncertain speculation about whether some other court would eventually grant indemnification, even if such indemnification is mandatory according to European Community law.

The Oberlandesgericht Munich quashed the decision on appeal. The appellate court did not question the possibility of entrusting the dispute to arbitrators as such, since this possibility was clearly confirmed in the legislative materials for the reform of the German arbitration law of $1998 .{ }^{37}$ It did, however, assess the impact of $\$ 89 \mathrm{~b} H G B$ on the effectiveness of the arbitration agreement quite differently than the Landgericht. The Oberlandesgericht rejected the defendant's argument that the provision's internationally mandatory nature would affect only choice-of-law, but not jurisdictional issues. Rather, the court accepted the claimant's reference to a line of German case law looking at the combined effects of choice-of-law and jurisdiction clauses, despite their theoretically distinct nature. ${ }^{38}$ The purely effectsoriented character of internationally mandatory rules would require protecting them against any contractual construction that could undermine the legislator's intended result. Accordingly, the necessity to ensure the application of the internationally mandatory rule could require prohibiting contractual derogations from the forum's jurisdiction. The court went on to reject the defendant's argument that it was clear whether the arbitrators would ignore the German provisions. In view of the provision's objective to protect agents, jurisdictional or arbitral clauses would have to be deprived of their effectiveness if there is a 'likely

\footnotetext{
35 BGH, 30 January 1961 [1961] Neue Juristische Wochenschrift 1061.

36 OLG München, 5 December 2005, docket no 15 HKO 23703/04 (unreported, summarised in the appellate decision cited $\mathrm{n} 4$ above).

37 Bundesregierung, 'Entwurf eines Gesetzes zur Neuregelung des Schiedsverfahrensrechts' (12 July 1996) BT Drucksache 13/5274, 34 (referring explicitly, inter alia, to $\$ 89 \mathrm{~b}$ HGB). 38 BGH, n 35 above at [1062].
} 
danger' that the foreign tribunal will not apply the mandatory German provision. The court seriously doubted that a court or arbitral tribunal sitting in California would come to the conclusion that German law needed to be applied, despite the parties' choice of Californian law and - ignoring Californian conflict of law rules assumed that Californian substantive law would prevail. Consequently, it denied the arbitration agreement's effectiveness and remanded the case to the Landgericht for a decision on the merits of the claim.

On the basis of the decision of the Oberlandesgericht Munich, the German position regarding the impact of internationally mandatory rules on the effectiveness of arbitration agreements can be summarized as follows: Disputes can be decided by arbitrators, unless it cannot be reasonably expected that German internationally mandatory provisions designed to govern the claim will be applied. It is the claimant seeking protection in German courts who bears the burden of proof for demonstrating that there is a substantial risk that the provisions will not be applied. The combination of clauses providing for arbitration or jurisdiction of a foreign court and for the application of foreign law, however, will usually suffice as prima facie evidence to establish a presumption that German internationally mandatory rules will probably be deprived of their effectiveness. ${ }^{39}$ In that case, the burden of showing the contrary is shifted to the party relying on the arbitration agreement.

\section{Criticism Against the Belgian and German Cases}

The Belgian line of case law has not really given rise to much criticism, but rather - in line with the French tradition - to some speculations as to the real meaning of the somewhat Delphic language of the Cour de cassation. ${ }^{40}$ The final German decision, in contrast, albeit welcomed by some authors without much comment, ${ }^{41}$ has been the object of serious criticism by some younger scholars. ${ }^{42}$ This criticism is directed against the court's simplicity of reasoning and lack of doctrinal foundation (1), as well as against the entire idea of rendering arbitration agreements ineffective because of internationally mandatory rules (2).

\footnotetext{
39 See the court's explicitly reference to BGH, ibid, which stated that, in case of doubt, the parties will probably have intended the law of the chosen forum to apply.

${ }^{40}$ See eg Hollander, $\mathrm{n} 27$ above.

41 K.H. Thume, 'Anmerkung zu OLG München, Urteil vom 17.5.2006 - 7U 1781/06' (2006) Internationales Handelsrecht 160; R. Emde, 'Kurzanmerkung zu zu OLG München, Urteil vom 17.5.2006' (2006) Europäisches Wirtschaftsrecht 621.

${ }^{42}$ G. Rühl, 'Extending Ingmar to Jurisdiction and Arbitration Clauses: The End of Party Autonomy in Contracts with Commercial Agents?' (2007) European Review of Private Law 891; D. Quinke, 'Schiedsvereinbarungen und Eingriffsnormen' (2007) SchiedsVZ 246; agreeing, N. Horn, 'Zwingendes Recht in der Internationalen Schiedsgerichtsbarkeit' (2008) SchiedsVZ 210, 217.
} 


\section{PUBLIC POLICY AS DEFINED FOR THE STAGE OF ENFORCEMENT}

\section{A CArte Blanche For Courts to Strike Down Arbitration AgreEMENTS?}

The solution of the Oberlandesgericht Munich has been attacked on the basis that it relies, without any jurisprudential foundation, on the vague criterion of a likely danger' that the forum's internationally mandatory rules would not be applied by the court or tribunal chosen by the parties. The critics have rightly pointed out, that the established pre-Ingmar case law, which the Munich court of appeal purports to follow, was based on a different criterion. Earlier German decisions had adopted a test focusing on the consequences of giving effect to the choice-offorum or arbitration clause: the clause would not be enforced if it could be anticipated that the enforcement of the foreign decision made in disregard of German internationally mandatory rules could be refused for being contrary to the German ordre public. 43

By abandoning this more restricted criterion, the Oberlandesgericht, according to the critics, would have created a kind of carte blanche for its appreciation of the actual danger for the effectiveness of the German mandatory rules of law. By confining itself to the 'likeliness' of the non-application of German mandatory law, the court contented itself with an intuitive and, in fact, sloppy prognosis of the probability that a foreign court or arbitral tribunal would disregard them. In order to illustrate the superficiality of the new approach, the critics rightly bash the Oberlandesgericht for completely ignoring that a Californian court, on the basis that $\$ 187(2)$ Restatement (Second) Conflict of Laws would maybe give the (European) fundamental policy underlying $\ 89 \mathrm{~b}$ HBG much more attention than the German court ever imagined. ${ }^{44}$

\section{Focusing on Public Policy at the Enforcement Stage}

The second reproach related to the departure from the previously accepted criterion is more important. Rather than differentiating between the likely application or non-application of German mandatory rules of law, the previous

\footnotetext{
43 Quinke, n 42 above, 248 and Rühl, n 42 above, 896-897, referring, inter alia, to: BGH, n 35 above at [1062]; ibid, 30 May 1983, [1983] NJW 2772; ibid, 26 February 1991, [1991] NJW-RR 757 at [758]; ibid, 21 September 1993, [1993] NJW-RR 1519 at [1520].

44 cf Rühl, n 42 above; see \$187(2) Restatement 2d Conflicts, n 3 above, which orders the court to have regard to the fundamental policy of the law that would be applicable in the absence of a choice; for its application in California, see eg Nedlloyd Lines B.V. v Superior Court of San Mateo County, 3 Cal. 4th 459 at [466] (Cal. 1992) (especially in n 5). But see Northrop Corp. v Triad Int'l Marketing S.A., 811 F.2d 1265 at [1270] (9th Cir. 1987) (where the court brushed aside the necessity to apply clearly mandatory Saudi Arabian law despite the choice of Californian law by citing from the Supreme Court's decision in Scherk, n 54 below: 'choice-of-law and choice-of-forum provisions in international commercial contracts are "an almost indispensable precondition to achievement of the orderliness and predictability essential to any international business transaction", and should be enforced absent strong reasons to set them aside'.)
} 
criterion focuses on whether the expected actual outcome of foreign proceedings would be incompatible with the German ordre public. Indeed, the criterion of the Oberlandesgericht - and, for that matter, of the Belgian courts - disregards the possibility that the foreign court or arbitral tribunal may well come to an acceptable result even in application of a totally different law. The 'likeliness of non-application' criterion actually falls short of capturing the real nature of an internationally mandatory rule: its instrumentality for implementing the legislator's eventual intention to impose a specific result to a given situation and to prohibit the parties from agreeing upon a materially different result. ${ }^{45}$ It follows from both Belgian or German constitutional law as well as from primary European Community law (which applies when a court of a Member State gives effect to Community law, even if only by applying national law that transposes a directive) that the parties' freedom of contract can only be restricted to the degree actually necessary for implementing a given public policy. ${ }^{46}$ Refusing to enforce an arbitration agreement under the pretext that, in combination with the choice of foreign law, it would lead to an award that is not rendered on the basis of internationally mandatory European law may well be disproportionate and thus contrary to constitutional or Community law, if the court does not take into consideration whether the foreign law affords a protection equivalent to that declared as internationally mandatory by the lex fori.

\section{WEAKNESSES OF THE CRITICISM}

However, these arguments are much less compelling than they may seem at first, even if they are mostly quite pertinent from a theoretical point of view. Regarding the first reproach, it is highly doubtful, as a matter of fact, that the Oberlandesgericht would have been less sloppy in its assumptions on Californian conflicts rules had it stuck to the more considerate pre-Ingmar criterion of German case law. Furthermore, the criticism disregards that the court's seeming superficiality reflects nothing else but the weakness of the arguments presented by the defendant who had the burden of showing that the effectiveness of German mandatory rules would not be imperilled by the combined choice-of-forum and choice-of-law

\footnotetext{
45 The EC directive as well as the Belgian act of 1861 merely impose a specific method of determining the indemnification or compensation. However, the method is imposed only for the sake of guaranteeing the agent or the distributor a variable merits-based benefit depending on the investments and achievements that actually profit the disloyal principal or provider.

${ }^{46}$ For the constitutional principle of proportionality as a restriction to limitations of contractual freedom, see in Germany, BVerfG, 12 November 1958 (Preisgesety) 8 BVerfGE 274 (1958) at [328]; in Belgium, eg Cour d'Arbitrage, 28 October 2004, SA Les AP Assurances / G. Van Leekwijck et H. Wouters (2005) 10 Revue de Droit Commercial Belge 1052 at [1054]. For the recognition of contractual freedom as protected by fundamental rights and thus subject to the principle of proportionality under EU law, see ECJ, 151/78, Sukkerfabriken Nykobing v Ministry of Agriculture [1979] ECR 1 at [1 22] (obiter); C-292/97, Kjell Karlsson and Others [2000] ECR I-2737 at [9 45], as well as generally Treaty Establishing the European Community (as amended by the Treaty of Amsterdam), (signed 25 March 1957, entered into force 1 January 1958), Art 5(3) (hereinafter 'EC Treaty'), which also binds judges of the Member States acting as Community judges by applying national law that transposes EC law: 'Any action by the Community shall not go beyond what is necessary to achieve the objectives of this Treaty.'
} 
clause. In any case, the argument that Californian courts would be obliged by their conflicts of law rules to be sensitive to German fundamental policy is of little support regarding the arbitration clause. Arbitrators are simply not bound by the conflict of law rules binding judges. It is far from clear on what basis the arbitrators would and should ignore the parties' explicit choice of Californian law and apply the European laws on which the claims are based. ${ }^{47}$ Ingenious arbitrators could even think that, if they opted for applying Californian conflicts rules, they would be obliged (under $\$ 187$ Restatement $2 \mathrm{~d}$ Conflicts) to take the European laws into consideration, but that they would be obliged to ignore them (under Article 9 of the Rome I Regulation) if they found that the European conflicts rules were the most appropriate ones for this question. ${ }^{48}$

Furthermore, it can be doubted that the ordre public criterion would lead to substantially less speculation about the eventual making of a future award in the sense of being more predictable or faithful to the parties' intention. Despite the fact that it is commonly accepted that the notion of public policy under Article $\mathrm{V}(2)(\mathrm{b}) \mathrm{NYC}$ has to be interpreted restrictively, it is very questionable whether the court would have come to a different conclusion had it relied on whether a prognosis of the arbitral award would violate German public policy. It is true that the court's analysis was somewhat short-sighted insofar as it only speculated about the application of German mandatory rules, instead of considering the possibility of an equivalent outcome based on the application of foreign law. However, predictability is hardly enhanced if the court, at the preliminary stage of deciding on whether to stay proceedings, first has to anticipate not only the arbitrators' decision, but also its own subsequent decision on recognition. ${ }^{49}$ Moreover, the court can hardly be expected to embark all alone upon an analysis of equivalence of the hypothetical outcome of arbitration under foreign law - at least not when the party seeking enforcement of the arbitration agreement did not even raise such a hypothesis. In view of the complex comparative challenge that such analysis would imply, 50 it can be doubted whether the equivalence test would lead to fewer

\footnotetext{
47 For the complex problems related to the application of mandatory rules from an arbitrator's perspective, see A.S. Rau, 'The Arbitrator and "Mandatory Rules of Law"' (2008) 18 Am. Rev. Int'l Arb. 51.

48 Under Art 9(3) Rome I Regulation, n 3 above, the possibility of applying 'overriding mandatory rules' is restricted to those of the law of the country of the performance of the contract which renders the contract unlawful. However, Art 1(2)(e) explicitly excludes arbitration from its scope of application, and, in any case, $\$ 1297.283$ of the Californian Code of Civil Procedure, as well as Art 28(1) ICDR/AAA Rules, dispense arbitrators from having to apply national conflict of law rules for determining the applicable law. For $\$ 187$ Restatement 2 nd Conflicts, see $n 3$ above.

49 cf ECJ, C-539/03, Roche Nederland BV and others v Frederick Primus and Milton Goldberg [2006] ECR I6535 at [0 39].

50 The indemnification or compensation of fired commercial agents is an excellent example for this: Rühl, n 42 above, 901-902 affirms that Californian law does not allow for claims for indemnification similar to that of the European Directive nor for any other compensation mechanisms that might serve as a functional equivalent, referring to Katz, 'United States' in: A. Jausàs (ed), International Encyclopedia of Agency and Distribution Agreements (New York: Aspen, 2000), 6. However, the picture is less clear when looking at the functional reasons for the European indemnification or compensation solution and comparing that
} 
unconsidered simplifications and thus to less uncertainty than the likeliness of non-application' approach.

\section{RESPECTING 'COMPETENCE-COMPETENCE’?}

Unsurprisingly, the criticism was not limited to the criterion employed. The fundamental reproach is that the position taken by the Oberlandesgericht - and the same would apply to the position of the Belgian courts - would be too restrictive to pay tribute to the needs of international transactions. ${ }^{51}$ Others have formulated this reproach more polemically: 'Parochial or discriminatory national laws cannot be the measure of how the validity of international arbitration agreements is determined.'52

This reproach of 'parochialism' has been borrowed from the famous passage by the U.S. Supreme Court's decision in Scherk v Alberto-Culver Co., which was also cited in Mitsubishi: 53

A parochial refusal by the courts of one country to enforce an international arbitration agreement would not only frustrate these purposes [ie achieving orderliness and predictability by specifying in advance the forum and the applicable law], but would invite unseemly and mutually destructive jockeying by the parties to secure tactical litigation advantages... [It would] damage the fabric of international commerce and trade, and imperil the willingness and ability to enter into international commercial agreements. ${ }^{54}$

The legitimate question raised in this context is: why not leave all safeguards for ensuring the respect for internationally mandatory rules to the stage of

with Californian law. European law allows commercial agency contracts and exclusive distribution contracts to contain non-compete clauses and the mandatory compensation and is in many countries directly linked to the length of the non-compete clauses, cf in Belgium Art 20(2) and $24 \$ 3$ of the Act of 13 April 1995 on commercial agency contracts (establishing that if the parties stipulated a non-compete clause, there is a presumption that the principal has drawn a substantial benefit from the contract and that the agent has acquired new clients - which are the two factors governing the calculation of the compensation due in case of termination according to Art 20(3)); in Germany $\$ 90 a(1)$ in fine (indemnification is due for the duration of the non-compete period). Californian law, in contrast, prohibits non-compete obligations because they are limitations to the freedom of enterprise protected by $\$ 16600$ of the Californian Business and Professions Act. Accordingly, Californian courts strike down any choice-of-law and choice-of-forum clauses designed to avoid this prohibition, which is considered to represent a 'very strong public policy', cf Comedy Club, Inc. v Improv West Assocs., 553 F.3d 1277 (9th Cir. 2009); Hill Med. Corp. v Wycoff, 86 Cal.App. 4th 895 at [900] (Cal. App. 2d Dist. 2001). It would not be too much of a stretch to consider that this approach of protecting commercial agents, albeit tackling the problem from a totally different angle, could possibly qualify as a functional equivalent. Although the final finding may eventually be different, this shows that a sound answer requires a comparative effort that exceeds by far the level that critics reproach the court not to have met.

51 Rühl, n 42 above, 302; Quinke, n 42 above, 252.

52 G. Born and J. Koepp, 'Towards a Uniform Standard of Validity of International Arbitration Agreements Under the New York Convention' in B. Bachmann, et al. (eds), Grenzüberschreitungen Festschrift für Peter Schlosser zum 70. Geburtstag (Tübingen: Mohr Siebeck, 2007), 73.

53 n 2 above at [631].

54417 U.S. 506 at [516-517]. 
enforcement, in line with the U.S. Supreme Court's 'second look' logic in Mitsubishi5s and with the commonly accepted principle of 'competencecompetence'? This was apparently the understanding of the lower German court, as well as explicitly that of the lower Belgian courts who relied on the lex contractus solution in the context of Article II(3) NYC. ${ }^{56}$ Indeed, the arguments in favour of this solution are powerful: it would be much more respectful of the parties' free choice to submit to arbitration; it would be more respectful of arbitrators who would be given a chance to do their job correctly; and, at first sight, it nevertheless seems to guarantee that the European distributor will receive the eventual benefit intended by the forum's international mandatory rules.

\section{Why it Could Work}

The solidity of this 'hands-off solution seems to be confirmed by a look at the worst case scenario, ie when the arbitrators simply ignore the European protective provisions and consequently reject the European party's claim on the basis of Californian law. ${ }^{57}$ In that case, there is simply nothing to be enforced in Belgium or Germany, probably not even costs..$^{58}$ It is worth noting that this scenario is much more likely than commonly admitted: ${ }^{59}$ the few published awards on cases of the kind discussed here show that arbitrators have preferred to respect the parties' choice and not to apply the 'foreign' internationally mandatory rules. ${ }^{60}$

Recognition of a 'purely Californian' award refusing to give effect to $\$ 89 \mathrm{~b}$ HGB or the Belgian Act of 1961 would be rejected in Germany and Belgium, respectively, on the basis of Article V(2)(b) NYC: such a refusal would constitute a

\footnotetext{
$55 \mathrm{n} 2$ above at [638]: 'Having permitted the arbitration to go forward, the national court of the United States will have the opportunity at the award-enforcement stage to ensure the legitimate interest in the enforcement of the anti-trust law has been addressed.'

${ }^{56}$ For the application of the 'second look' doctrine to awards involving competition law issues, see in Germany, OLG Dresden, 20 April 2005 [2005] SchiedsVZ 210 at [211]; in Belgium, Trib. com. Bruxelles, 8 March 2007, SNF v Cytec [2007] Revue de l'Arbitrage 303 (but see the opposite position taken by French courts in the same case: Cass., 4 June 2008 [2008-I] Bull.civ. no 162); see also the ECJ in EcoSwiss $\mathrm{v}$ Benetton, $\mathrm{n} 2$ above at [32]: 'where questions of Community law are raised in an arbitration resorted to by agreement, the ordinary courts may have to examine those questions, in particular during review of the arbitration award, which may be more or less extensive depending on the circumstances and which they are obliged to carry out in the event of an appeal, for setting aside, for leave to enforce an award or upon any other form of action or review available under the relevant national legislation.'

57 See $n 50$ above.

${ }^{58}$ Except if the parties have previously agreed on, or the institutional rules allow, the recovery of attorney fees from the unsuccessful party, Cal. Civ. Code $\$ 1717$. For the insufficiency of the AAA Commercial Arbitration Rules in this respect, see Asturiana De Zinc Mktg. v LaSalle Rolling Mills, 20 F. Supp. 2d 670 at [675] (S.D.N.Y. 1998).

${ }^{59}$ See J. Erauw, 'The Arbitrability of Disputes Concerning the Termination of Distribution Agreements under Belgian Law in Light of European Community Law' in: idem et al (eds), Liber Memorialis Petar Sarcevic: Universalism, Tradition and the Individual (München: Sellier, 2006), 434: 'it is unlikely that arbitrators would be so inconsiderate towards the legal system of a country where the parties will inevitably request enforcement of the award'.

${ }^{60}$ ICC case no 6379, XVII YB Comm. Arb. 212 (1990) (refusing to apply Belgian law, despite the fact that an action in Belgian courts was also pending). See also CA Paris, 24 November 2005 [2006] Revue de l'Arbitrage 717 (rejecting the Belgian party's request for setting aside based on the non-application of the Belgian provision on commercial agency).
} 
violation of that country's strong public policy as enshrined in its internationally mandatory rules which aim at guaranteeing indemnification or compensation to commercial agents irrespective of the law chosen by the parties. ${ }^{61}$ Moreover, once the award has been rendered, the public policy exception would also allow the German or Belgian court to reject the arbitration agreement's effect since, at that stage, it is then clear that the combined arbitration and choice-of-law clause leads to the non-application of the internationally mandatory rule of the forum. This means that the court would now entertain the agent's or distributor's claim and grant indemnification or compensation according to its legislator's intention. Those European judgments may be unenforceable in California due to the res indicata effect of the earlier Californian award, which will certainly not be set aside in California. The threat of execution measures against the Californian merchandise coming into Europe, however, may well prove sufficiently persuasive for obtaining payment.

\section{Why it Would Not Work}

This solution à la Mitsubishi, however, is not unproblematic. If it is foreseeable from the outset that the arbitrators sitting abroad will most probably not apply the internationally mandatory rules, it is highly problematic to refer the 'protected' party to an arbitration that is expensive (requiring them to hire a lawyer in California), time consuming (when the termination without compensation may already put the former agent into problems of liquidity), and, moreover, useless because it is lost in advance. This solution is plainly contrary to the logic of procedural economy. Turning back to the Scherk argument, this solution would mean that choice-of-law and choice-of-forum clauses were to be upheld for the sake of 'orderliness and predictability' in international contracts - but at the expense of the certainty that the legislator intended to guarantee to distributors by defining a stable basis of their operations in an internationally mandatory rule of law. ${ }^{62}$

However questionable the ECJ's policy considerations in Ingmar may be, its ruling that the rules on compensation for commercial agents are internationally as opposed to merely domestic - mandatory is in line with the effects-oriented logic that defines this controversial category of rules. The EC Directive of 1986 explicitly introduced the protection of commercial agents because '[national] differences [in the protection of commercial agents] are such as to inhibit substantially the conclusion and operation of commercial representation contracts where principal and commercial agents are established in different Member States'

\footnotetext{
${ }^{61}$ For Germany, see Quinke, n 42 above, 250; for Belgium, see n 21 above.

62 cf Solman Distribs. v Brown-Forman Corp., 888 F.2d 170, 172 (1st Cir. 1989) (in a U.S. inter-state case on choice-of-law clause in favour of Californian law in a Maine distribution contract, thus not referring directly to Scherk: 'Defendant merely contends the state recognizes that its business has the necessity of "certainty". This is to ignore that there would be a corresponding uncertainty on plaintiff's part. A distributor's uncertainty, its economic livelihood, may readily be thought at far greater risk, having in mind that the [producer] can always cancel freely if it is not receiving proper performance.').
} 
and because 'trade in goods between Member States should be carried on under conditions which are similar to those of a single market, and this necessitates approximation of the legal systems of the Member States to the extent required for the proper functioning of the common market', so that 'in this regard the legal relationship between commercial agent and principal must be given priority' in the process of harmonizing the law. ${ }^{63}$ This shows that the protection of the commercial agent was not primarily introduced for the mere sake of some individuals acting as agents, but for an underlying fundamental public policy: overcoming a particular obstacle to the good functioning of the internal market. Commercial agents are, in a community of economically and culturally highly heterogeneous and diversified countries, essential for opening markets across borders. Only where suitable local agents (also in view of the linguistic differences) can be found abroad can a domestic producer reach for new markets. Commercial agents are considered to be the structurally weaker party at the time of the conclusion of the contract because they, typically individuals, face much larger economic entities as their counterparts. Self-employed agents are considered to be particularly vulnerable to abrupt termination because of their necessary investment in building knowhow and client relationships. In summary, the European logic is that protecting commercial agents also benefits their principals: the economic risks related to acting as a commercial agent are reduced by mandatory rules so as to stimulate people to engage in this activity, which in turn increase the producers' chances to operate across borders, and thus enhance the internal market.

The ECJ in Ingmar insists that the aim of the European legislator would be seriously undermined if the intended protection could be eliminated by means of contractual derogations in favour of foreign laws before foreign tribunals. The effet utile of the Directive would be undermined if agents were de facto deterred from claiming their lawful compensation in cases where the non-EC principal managed to stipulate choice-of-forum and choice-of-law clauses to keep claims away from European courts and thus from the result intended by the European legislator. It thus follows from the Member States' obligation to render European directives fully effective under Articles 10 and 249 EC Treaty that their courts also have the obligation to protect internationally mandatory rules from being de facto deprived of their efficacy.64 And the Scherk argument can be echoed here once again: enforcing arbitration and choice-of-law agreements in order not to 'imperil businessmen's willingness to enter into international commercial agreements' could mean ignoring that the European internationally mandatory rules of law, by protecting agents, are precisely designed to ensure the establishment and good

\footnotetext{
${ }^{63}$ Recitals 6 (in fine) and 7 of Council Directive 86/653/EEC, $\mathrm{n} 27$ above.

${ }^{64} \mathrm{cf}$ EC Treaty, n 46 above, art 10: 'Member States shall take all appropriate measures, whether general or particular, to ensure fulfilment of the obligations arising out of this Treaty or resulting from action taken by the institutions of the Community. They shall facilitate the achievement of the Community's tasks. They shall abstain from any measure which could jeopardise the attainment of the objectives of this Treaty.'
} 
functioning of the internal market, ie the foreign businessmen's opportunities to enter into commercial agreements for accessing new markets.

Some may question whether the policies underlying the EC Directive or the Belgian Act of 1961 are strong enough (or even justified) so as to require their implementation even against explicit choice-of-law clauses entered into by (supposedly) experienced businessmen. ${ }^{65}$ Maybe the reproach of parochialism is not all that far fetched. However, the ECJ's Ingmar decision is the law as it stands and is binding for, and needs to be given effect by, the national courts of the Member States. The same holds true for Belgian courts regarding the Belgian Act of 1961. The judges are obliged to ensure the effectiveness of internationally mandatory rules of their legal order. It thus seems inevitable that Belgian and German courts must not give effect to arbitration clauses where it is reasonably foreseeable that the outcome of the arbitration will be contrary to the fundamental policy of the lex fori. Or...maybe not?

\section{A LitTlle Twist That Will Do the Trick}

When dwelling some more on the concepts of European Community law, but also on those regarding the constitutionality of sovereign acts, it becomes clear that a final answer to the question depends on the test of proportionality. A measure implementing public policy at the expense of individual rights is only compatible with fundamental rights (including the freedom of contract) if there is no alternative measure that is as effective in obtaining the policy aim, but less restrictive on individual rights than the proposed measure.66 Is there such an alternative solution that is as effective in ensuring the application of the protection of agents or distributors, but still less restrictive of the parties' right to agree on arbitration? In fact, there is one.

The hint to this can be found in the very decision that was crucial for moving away from general exclusions of certain matters from arbitration towards dealing with public policy in terms of ensuring application of mandatory rules: the Mitsubishi decision of the U.S. Supreme Court. What made the Supreme Court reverse an order by which the 5th Circuit Court of Appeals found that antitrust claims brought by a car dealer in the context of the termination of an distribution agreement would not be capable of settlement by arbitration? Why did the Court accept to have that kind of dispute, to which the Sherman Act clearly was intended to apply, decided by an arbitral tribunal of three Japanese arbitrators sitting in Japan when the law chosen by the parties to govern the contract was Swiss law?

It was not only the manifold policy considerations that the Supreme Court elaborated in its judgment, but also an imminently practical one. The Court noted in the highly controversial footnote 19 'that in the event the choice-of-forum and

65 See Rühl, n 42 above, 903: 'The decision of the OLG München incurs the risk of seriously undermining party autonomy in Europe. Whether this is in the best interests of the Internal Market is very much open to doubt.'

${ }^{66}$ n 46 above. 
choice-of-law clauses operated in tandem as a prospective waiver of a party's right to pursue statutory remedies for antitrust violations, we would have little hesitation in condemning the agreement as against public policy'. ${ }^{67}$ This suggests that, at the outset, the Court took more or less the same position as the Belgian and German courts. However, a factual detail given in the same footnote shows why the Supreme Court did not feel the need to condemn the parties' agreement providing for arbitration in Japan according to Swiss law: 'a]t oral argument, however, counsel for Mitsubishi conceded that American law applied to the antitrust claims and represented that the claims had been submitted to the arbitration panel in Japan on that basis. ${ }^{6} 68$

Irrespective of the controversy over what the Supreme Court actually meant in footnote 19, the approach of seeking a commitment that those - and only those - issues intended to be governed by the forum's internationally mandatory rules of law shall be governed by them irrespective of the lex contractus is most pragmatic and efficient. Indeed, this seems to be the most convincing key to solving the state courts' dilemma between respecting the parties' original intention to arbitrate and their legislators' intention to protect specific public interests. It is for the parties to give the judge the elements that he or she needs for a decision on the impact that the relevant internationally mandatory rules are to have in their dispute. The court is bound by its constitution, from which it derives its jurisdictional powers, to give effect to the internationally mandatory rules irrespective of the parties' agreement. The court simply cannot accept that its mandatory rules be diluted to 'semimandatory' rules because of arbitration. ${ }^{69}$ If circumstances indicate that this efficacy could be jeopardized by the parties' contractual construction, the court must verify if there is some kind of safeguard that would justify respecting the parties' choice of arbitration without compromising its duty to uphold the effect of the internationally mandatory rule of law. At this point, it is the burden of the party relying on the arbitration agreement to provide the necessary clarification.

The situation in which there is no choice-of-law clause should be rather unproblematic, so long as the applicable conflict of law rules can be expected to lead the law of the country whose fundamental policy is in question. ${ }^{70}$ Where the parties have submitted their contract to foreign law, the party requesting the referral to arbitration can try to convince the court that the protection afforded by the lex contractus is equivalent to that of the lex fori. If such equivalence is doubtful or simply not given (such as probably in the cases discussed here), that party's last

\footnotetext{
67473 U.S. 614 at [637 n.19].

68 ibid.

${ }^{69}$ But see the concept of 'lois d'application semi-nécessaire' by L. Radicati di Brozolo, 'Mondialisation, Juridiction, Arbitrage: Vers des Règles d'Application Semi-Nécessaires?' (2003) Revue Critique de Droit International Privé 1; H. Muir Watt, 'Choice of Law in Integrated and Interconnected Markets: A Matter of Political Economy' (2003) 9 Colum. J. Eur. L. 383, 407.

${ }^{70}$ See eg Art 6 of the Hague Convention of 14 March 1978 on the law applicable to agency at $<$ http://www.hcch.net/index_en.php?act=conventions.text\&cid=89>; Art 4(1)(b) and (f) Rome I Regulation (for agency [= service] and distribution contracts), n 3 above.
} 
resort is, as in Mitsubishi, explicitly to state that it expects and accepts the arbitral tribunal to apply the internationally mandatory rules of the forum state. In that case, the court can then record this acceptance and take it - the consent of the party resisting arbitration presumed - as a new choice-of-law agreement that is specifically concluded for, and limited to, the question of the application of the internationally mandatory rules. Such a contractual stipulation by the parties will thereby become binding upon the arbitrators. This dépeçage will allow the court to conclude that the application of its internationally mandatory rules is not imperilled by the choice of arbitration and can thus justify staying proceedings or - which is less fortunate, but necessary under German and Belgian law - to decline its jurisdiction in favour of the arbitral tribunal. ${ }^{71}$

\section{CONCLUDING REMARKS}

The intermediate solution proposed here should allow courts to respect both the original intention of the parties to arbitrate and the intention of the legislator to enforce certain public policies even in international situations. The underlying difficulty eventually boils down to the parties' (or rather the producer's) original fallacy to think that they can choose both a 'foreign' forum and foreign law for their dispute and thereby subtract their dispute from the courts of the country which has an immediate interest in the outcome of the dispute and so evade the application of that country's internationally mandatory rules. It is a logical consequence from the courts' obligation to give effect to their internationally mandatory rules that courts are forced to break at least one of those two legs of the agreement. This dilemma can be resolved by focusing on the fundamental nature of internationally mandatory rules: they are designed to assure that the parties cannot derogate from the result wanted by the legislator, neither through substantive contractual stipulations ('mandatory') nor through the choice of foreign law ('internationally'). Bearing in mind that state intervention needs to be restricted to what is actually necessary to implement public policy at stake, it is sufficient and thus appropriate first to tackle the choice-of-law agreement only, and only partially. The court can expect the party that invokes the arbitration agreement to guarantee the application nécessaire of the internationally mandatory rules in arbitration proceedings, ie to accept a new limited choice-of-law agreement acknowledging the rules' application according to the intention of the forum's legislator. This allows re-establishing the original contractual equilibrium.

\footnotetext{
${ }^{71}$ See also in Belgium, CA Bruxelles, 30 June 2006 [2004] Rechtspraak Antwerpen Brussels Gent 1301: 'In view of the effects of the concession on the Belgian territory and the fact that the parties agree on this, there is no reason that the arbitral tribunal will not apply the mandatory rules of the Belgian act on concessions [despite the general choice-of-law agreement in favour of Dutch law].' Similarly already A. Nuyts, La Concession de Vente Exclusive, l'Agence Commerciale et l'Arbitrage (Paris: Bruylant, 1996), 19, 73.
} 
On one hand, the (domestic) claimant must accept being bound to his original consent to arbitrate, but at the benefit of obtaining certainty that he can effectively pursue his statutory rights (especially since a favourable foreign arbitral award will be much more effective than a domestic court judgment, which will probably be unenforceable in the defendant's home country). On the other hand, the (foreign) defendant must accept that the choice of a foreign law cannot free him from the obligations imposed on him as conditions for his economic activity in the forum state's territory. Yet this acceptance comes at the benefit of obtaining a more neutral and maybe more competent forum - a forum that, when appreciating the claims by the European distributors, will not be bound by a predetermined result, but merely by the performance-oriented parameters defined by the European internationally mandatory rules,hich means that if the distributors performed poorly, their rights - even under the protective European legislation may well be minimal or even zero. ${ }^{72}$ All in all, this re-balanced setting should provide for a healthy stimulus for parties to strike a mutually fair settlement rather than - to return to the language of Scherk - invite 'unseemly and mutually destructive jockeying by the parties to secure tactical litigation advantages'. ${ }^{73}$

In a broader context, a possible objection to the solution proposed here could be that it puts significant strain on the conception of Article II(3) NYC. The aim of the provision is to establish a presumption of validity of the arbitration agreement and to impose the burden of proving the contrary on the party opposing arbitration. Burdening the party that seeks arbitration to show the equivalence of the protection afforded by the foreign law or to avouch the application of the mandatory rules may, at first sight, seem to undermine the original logic upon which Article II(3) was built. This argument, however, falls short of the prevailing - and correct - view that Article II(3) is to be interpreted as following the same logic as Article V(2)(a) and (b). Courts may rely on their lex fori for determining whether the dispute is capable of settlement by arbitration, at least when their own public policy is at stake. It is therefore fully in line with the structure of the New York Convention that courts can raise the issue ex officio and expect assurance that the effectiveness of their internationally mandatory rules will not be cancelled by the arbitration agreement.

Moreover, it has to be borne in mind that the New York Convention was drafted in a pre-Scherk and pre-Mitsubishi world of arbitration, in which subject matters touching upon fundamental policies of the forum state were simply not be capable of settlement by arbitration. The traditional bright-line solution of lack of arbitrability enshrined in Article $\mathrm{V}(2)(\mathrm{a})$, which excluded virtually all sensitive matters from arbitration, is also the justification for the courts' considerable deference to arbitrators' decisions. It was the exclusion of sensitive matters that legitimised the extremely narrow interpretation of the public policy exception

\footnotetext{
72 See $\mathrm{n} 45$ above.

${ }^{73} \mathrm{n} 54$ above at [517].
} 
under Article $\mathrm{V}(2)(\mathrm{b})$ and the resulting general exclusion of any judicial review of the merits of the award. Scherk and Mitsubishi and their repercussions in numerous jurisdictions have sensitively changed the original balance struck between Article $\mathrm{V}(2)(\mathrm{a})$ and (b). The result of the massive liberalisation of arbitrability, ie the lowering - if not tearing down - of the ex ante filter of Article $\mathrm{V}(2)(\mathrm{a})$, comes necessarily at the price of some increase in judicial ex post control of the compatibility of the arbitrator's decision with public policy. The Supreme Court's sketch in Mitsubishi of courts having a 'second look' is indeed most persuasive where the effectiveness of internationally mandatory rules is designed and enacted democratically to enforce a strong public policy. ${ }^{74}$ The legitimacy, and thus the success of arbitration itself, might be at stake if courts allow arbitration to become a means for circumventing such protective public policies, as hinted at by the proposals for a 'Fairness in Arbitration Act'. ${ }^{75}$ It is all about finding the right balance. And accepting a well-balanced impact of internationally mandatory rules of law at the stage of judicial control of arbitration agreements under Article II(3) NYC as suggested in this paper may well be a good way of fortifying the legitimacy of international arbitration.

\footnotetext{
${ }^{74}$ See the harsh and pertinent criticism against Baxter Laboratories, Inc. v Abbot Int'l, 315 F.3d 829 (7th Cir. 2003) by R. Buxbaum, 'Public Law, Ordre Public and Arbitration: A Procedural Scenario and A Suggestion' in P. Hay, L. Vekas, Y. Elkana, and N. Dimitrijevic (eds), Resolving International Conflicts: Liber Amicorum Tiber Varady (Budapest: CEU Press, 2009). In a similar vein, see Posner and Guzman, n 1 above.

75 cf D.D. Caron and S. Schreiberg, 'Anticipating the 2009 U.S. 'Fairness in Arbitration Act' (2008) 2.3

World Arbitration and Mediation Review 15.
} 